\title{
PENERAPAN STRATEGI SELF-MANAGEMENT DALAM BIMBINGAN KELOMPOK UNTUK PEMANTAPAN PEMILIHAN KARIER PADA SISWA SMA
}

\author{
Niken Anisa Putri, Bambang Susanto, Panggih Wahyu Nugroho \\ Universitas Veteran Bangun Nusantara \\ anisaputri110599@gmail.com
}

\begin{tabular}{l|l}
\hline Article Info & \multicolumn{1}{c}{ ABSTRAK } \\
\cline { 1 - 2 } $\begin{array}{l}\text { Available } \\
\text { online }\end{array}$ & $\begin{array}{l}\text { Tujuan penelitian ini untuk membuktikan peran guru BK SMA dalam } \\
\text { meningkatkan minat melanjutkan studi ke perguruan tinggi. Metode penelitian yang } \\
\text { digunakan peneliti adalah metode kualitatif, maka jenis penelitian ini termasuk } \\
\text { dalam kategori penelitian kepustakaan. Pengumpulan data diperoleh dari buku- } \\
\text { buku ilmiah, laporan penelitian, karangan-karangan ilmiah, tesis, disertasi, } \\
\text { peraturan-peraturan, buku tahunan, ensiklopedia, dan sumber-sumber tertulis yang } \\
\text { lain. Faktor pengaruh minat ada 2 yaitu faktor internal dan faktor eksternal. Dari } \\
\text { hasil penelitian minat melanjutkan studi ke perguruan tinggi pada peserta didik } \\
\text { menunjukkan hasil yang cukup tinggi, dengan alasan pendidikan adalah hal yang } \\
\text { penting bagi mereka dalam meraih cita-cita. Berdasarkan dari hasil penelitian dapat } \\
\text { diketahui mengenai keberhasilan bahwa peran guru BK SMA dapat meningkatkan } \\
\text { minat melanjutkan studi ke perguruan tinggi. }\end{array}$ \\
& $\begin{array}{l}\text { Kata kunci: Peran guru BK SMA, Minat, Faktor-Faktor Yang Mempengaruhi Minat } \\
\text { Melanjutkan Studi Ke Perguruan Tinggi }\end{array}$ \\
\hline
\end{tabular}

\section{PENDAHULUAN}

Sumber Daya Manusia (SDM) merupakan salah satu faktor kunci dalam pembangunan bangsa dan negara. Kualitas SDM dipandang sebagai salah satu faktor kunci dalam era perdagangan bebas di zaman yang serba canggih seperti sekarang ini. Semakin tinggi persaingan dan tuntutan di dalam dunia kerja, juga membutuhkan SDM yang berkualitas dengan segala kompetensi yang dimiliki, serta mampu untuk mengembangkan diri secara optimal. Salah satu cara untuk meningkatkan kualitas SDM yaitu dengan melalui jalur pendidikan.

Pendidikan pada hakekatnya adalah usaha sadar dan terencana untuk mewujudkan suasana belajar dan proses pembelajaran agar peserta didik secara aktif dapat mengembangkan potensi dirinya untuk memiliki kekuatan spiritual keagamaan, pengendalian diri, kepribadian, kecerdasan, akhlak mulia, serta keterampilan yang diperlukan dirinya, masyarakat, bangsa, dan negara. Dengan pendidikan diharapkan dapat membentuk manusia 
yang mampu menguasai ilmu pengetahuan dan perkembangan teknologi yang dibutuhkan untuk membangun Indonesia.

Jalur pendidikan dibedakan menjadi tiga, yaitu pendidikan formal, pendidikan nonformal, dan pendidikan informal. Pendidikan formal merupakan pendidikan yang diselenggarakan di sekolah-sekolah pada umumnya. Jenjang pendidikan pada pendidikan formal terdiri dari : (1) pendidikan dasar: Sekolah Dasar (SD), Sekolah Menengah Pertama (SMP), (2) pendidikan menengah: Sekolah Menengah Atas, Sekolah Menengah Kejuruan (SMK), dan (3) pendidikan tinggi (Diploma, Sarjana).

Pendidikan dasar adalah pendidikan awal selama sembilan tahun pertama masa sekolah anak-anak. Diselenggarakan enam tahun di SD dan tiga tahun di SMP atau satuan pendidikan sederajat. Pendidikan dasar menjadi dasar bagi jenjang pendidikan menengah. Pendidikan dasar bertujuan memberikan bekal kemampuan dasar kepada peserta didik untuk mengembangkan kemampuannya sebagai pribadi, anggota masyarakat, warga negara, dan anggota manusia serta mempersiapkan peserta didik untuk mengikuti pendidikan menengah.

Pendidikan menengah adalah pendidikan pada jalur pendidikan formal yang merupakan lanjutan pendidikan dasar yang lamanya tiga tahun. Pendidikan menengah terdiri atas pendidikan menengah umum dan pendidikan menengah kejuruan. Tujuan pendidikan menengah untuk melanjutkan dan meluaskan pendidikan dasar serta mempersiapkan peserta didik menjadi anggota masyarakat yang memiliki kemampuan mengadakan hubungan timbal balik dengan lingkungan sosial, budaya, dan alam sekitar serta dapat mengembangkan kemampuan lebih lanjut dalam memasuki dunia kerja maupun pendidikan selanjutnya yaitu pendidikan tinggi.

Jenjang selanjutnya yaitu pendidikan tinggi dengan segala penyelenggaraannya. Pendidikan tinggi adalah tahap akhir opsional pada pendidikan formal. Perguruan tinggi terdiri dari beberapa bentuk, yaitu: universitas, institut, sekolah tinggi, politeknik, akademi, dan akademi komunitas. Peserta didik di perguruan tinggi disebut mahasiswa, sedangkan tenaga pendidiknya disebut dosen. Pendidikan tinggi bertujuan untuk mempersiapkan peserta didik yang memiliki kemampuan profesional yang dapat menerapkan, mengembangkan, dan menciptakan ilmu pengetahuan dan teknologi (IPTEK).

Guru adalah seorang yang berprofesi sebagai pengajar dan pendidik. Bisa dikatakan bahwa guru merupakan pemegang kendali yang sangat menentukan kualitas SDM di suatu negara. 
Guru yang berkualitas dan profesional akan menghasilkan murid yang berkualitas pula. Demi tujuan tersebut maka peningkatan kualitas guru adalah hal yang mutlak dan tidak dapat ditawar lagi (Noor, 2019: 1). Jadi, guru merupakan seseorang yang sangat dihargai karena telah berjasa dalam memberikan bekal berupa ilmu dan pengetahuan untuk kehidupan peserta didik dan akan selalu dikenang jasanya sebagai seorang guru oleh peserta didik. Pada proses peningkatan minat untuk melanjutkan studi ke perguruan tinggi guru yang sangat berjasa dalam hal ini adalah guru BK, yang mempunyai tugas untuk mengembangkan potensi yang dimiliki oleh peserta didik.

Menurut Prayitno (dalam Limbong: 2017) bimbingan adalah proses pemberian bantuan yang dilakukan yang ahli kepada seseorang atau beberapa orang individu, baik anak-anak, remaja, atau orang dewasa, agar orang yang dibimbing dapat mengembangkan kemampuan dirinya sendiri dan mandiri dengan memanfaatkan kekuatan individu dan sarana yang ada dan dapat dikembangkan berdasarkan norma-norma yang berlaku. Sedangkan Rukaya (2019: 8) mengemukakan bahwa bimbingan adalah proses pemberian bantuan yang dilakukan secara berkesinambungan atau terus menerus agar individu dapat memahami dirinya, sehingga dia mampu menentukan pilihannya sendiri.

Menurut Suherman (dalam Susanto, 2018: 6) mendefiniskan konseling merupakan hubungan yang bersifat membantu agar konseli dapat tumbuh ke arah yang dipilihnya juga agar dapat memecahkan masalah-masalah yang dihadapinya. Berbeda dengan Sundah (2018: 14) yang mengemukakan bahwa konseling merupakan suatu hubungan profesional antara seorang konselor yang terlatih untuk membantu konseli. Bantuan yang diberikan konselor kepada konseli terkait dengan masalah yang dialami konseli merupakan suatu proses. Dan sasaran proses konseling bersifat pribadi tiap individu. Konseling dilakukan kepada individu terutama agar konseli mengenal dirinya serta mengatasi permasalahannya.

Dari beberapa definisi di atas, dapat disimpulkan bimbingan merupakan proses bantuan yang diberikan kepada individu agar individu dapat mencapai perkembangan diri yang optimal. Sedangkan konseling merupakan proses kegiatan antara konselor dan konseli dalam rangka pemberian bantuan yang dilakukan untuk memahami diri dan permasalahan yang dihadapi konseli yang merupakan sebuah proses terpadu dari bimbingan. Konseling juga merupakan salah satu layanan utama yang dilaksanakan oleh seorang konselor atau guru BK. 
Menurut Slameto (2015: 180) minat adalah suatu rasa lebih suka dan rasa ketertarikan pada suatu hal atau aktivitas, tanpa ada yang menyuruh. Minat pada dasarnya adalah penerimaan akan suatu hubungan antara diri sendiri dengan sesuatu di luar diri. Semakin kuat atau dekat hubungan tersebut, semakin besar minat. Minat sering dihubungkan dengan keinginan atau ketertarikan terhadap sesuatu yang datang dari dalam diri seseorang tanpa ada paksaan dari luar. The Liang Gie (dalam Syahputra, 2020: 12) mengungkapkan bahwa atau terlibat sepenuhnya dengan suatu kegiatan karena nat berarti sibuk, tertarik, menyadari pentingnya kegiatan itu. Dengan adanya minat, mampu memperkuat ingatan seseorang terhadap apa yang telah dipelajarinya. Sehingga dapat dijadikan sebagai fondasi seseorang dalam proses pembelajaran di kemudian hari. Minat mengarahkan perbuatan kepada suatu tujuan dan merupakan dorongan bagi perbuatan tersebut. Dalam diri manusia terdapat dorongan-dorongan yang manusia untuk berinteraksi dengan dunia luar, motif menggunakan dan menyelidiki dunia luar (manipulate and exploring motives).

Dari beberapa pernyataan minat di atas menurut beberapa ahli dapat di simpulkan bahwa minat adalah suatu rasa ketertarikan pada suatu perhatian atau aktivitas yang dilakukan sendiri tanpa ada yang menyuruh. Semakin kuat atau dekat hubungan tersebut, semakin besar pula minat. Jadi semakin banyak seseJorang mengetahui tentang perguruan tinggi akan semakin tinggi minat untuk melanjutkan pendidikan ke perguruan tinggi. Bukan hanya dibutuhkan minat untuk melanjutkan ke perguruan tinggi tetapi juga sangatlah dibutuhkan seorang guru yang sangat kompeten dan sangat mendukung serta memberikan motivasi kepada siswa untuk mengembangkan potensinya dengan baik.

Pendidikan bertujuan untuk mengembangkan potensi dalam diri peserta didik agar memiliki keterampilan yang bertujuan menjadikan peserta didik memiliki spiritualitas dan akhlak. Namun pada kenyataannya pendidikan belum mampu memerankan tugas dan fungsinya secara optimal. Hal ini terlihat bahwa masih banyak peserta didik yang belum mampu mengaktualisasikan potensi yang dimiliki. Potensi-potensi yang ada pada diri mereka tidak dapat berkembang secara optimal, mereka yang berbakat tidak dapat mengembangkan bakat mereka secara baik, yang berkecerdasan tinggi kurang mendapat rangsangan dan fasilitas pendidikan sehingga bakat dan kecerdasan yang dimiliki terbuang sia-sia dan tidak dapat tersalurkan dengan baik. 
Fenomena pendidikan di Indonesia di mana institusi pendidikan belum mampu berperan secara optimal dalam perkembangan SDM. Sekolah-sekolah cenderung mengutamakan kuantitas dan prestise bukan kualitas dan prestasi yang dimiliki oleh peserta didik, sehingga pengembangan potensi peserta didik kurang mendapatkan perhatian. Salah satu upaya sekolah adalah menanamkan dan mengembangkan secara terus-menerus tentang kultur atau budaya sekolah. Sampai saat ini komitmen tentang kultur sekolah adalah disiplin, tertib dan bersih. Budaya ini harus tertanam dan melekat kepada semua warga sekolah tanpa kecuali. Ada satu pengharapan apabila kultur sekolah telah berjalan dengan baik tentunya program BK akan terlaksana secara efektif. Melihat situasi di atas peneliti tertarik untuk mengadakan penelitian pustaka dengan judul “PERAN GURU BK SMA DALAM MENINGKATKAN MINAT MELANJUTKAN STUDI KE PERGURUAN TINGGI “.

\section{METODE PENELITIAN}

Menurut Neuman (dalam Hamzah: 2020) berpendapat bahwa metode adalah serangkaian prinsip abstrak yang menawarkan panduan terbatas. Metode kepustakaan adalah cara kerja ilmiah yang tergolong dalam jenis penelitian kualitatif. Sedangkan menurut Furchan dan Maimun (dalam Hamzah: 2020) menyebut metode penelitian kepustakaan merupakan bagian dari studi tokoh yang berada pada kuadran empat tingkat, yaitu penelitian kualitatif tingkat tinggi. Penelitian kualitatif adalah prosedur penelitian yang menghasilkan data berupa ucapan atau tulisan dan perilaku orang-orang yang diamati dalam waktu konteks tertentu, dikaji dari sudut pandang yang utuh, komperehensif, dan holistik.

Peneliti dalam penelitian ini menggunakan analisis buku teks. Analisis buku teks adalah buku-buku pelajaran sekolah dasar sampai ke perguruan tinggi. Analisis buku teks di pelajaran sekolah, biasanya bersifat evaluasi untuk mengukur relavansi materi buku dengan perkembangan sosial budaya masyarakat dan perkembangan teknologi mutakhir. Khusus penelitian kepustakaan referensi perguruan tinggi, lebih bersifat pengembangan atau implementasi teori yang telah ada dengan perkembangan sosial budaya masyarakat. 


\section{Desain Penelitian}

\begin{tabular}{lcl}
\hline Tahap Perencanaan & Tahap Pelaksanaan & Hasil Akhir \\
\hline a. Identifikasi Masalah & a. Menentukan Metode & a. Kesimpulan \\
b. Menetapkan Tujuan & Kepustakaan & b. Saran \\
dan Kegunaan & b. Pengumpulan Data & \\
Penelitian & & \\
c. Metode Analisis & & \\
d. Sumber Data & & \\
\hline
\end{tabular}

\section{Uji Keabsahan Data}

Pada dasarnya, ketika melakukan validasi hasil penelitian, maka pada saat yang sama uji keabsahan data dilakukan. Pemeriksaan keabsahan data merupakan kegiatan akhir pada penelitian kualitatif. Namun, jika diperlukan data baru untuk memperkuat temuan, maka peneliti dapat melakukan pengambilan data yang dibutuhkan. Pemeriksaan keabsahan data dilakukan untuk memastikan hasil analisis dan interpretasi data dapat dipercaya. Menurut Guba (dalam Hamzah: 2020), melakukan pemeriksaan keabsahan data dilakukan dengan teknik credibility, transferability, dan confirmability. Sedangkan menurut Creswell (dalam Hamzah: 2020), memeriksa keabsahan data dengan cara member cheking, transferability, confirmability, triangulasi, dan external audit.

\section{Analisis Data}

Menurut Borgdgan \& Biklen (dalam Hamzah: 2020) berpendapat bahwa analisa data kualitatif termasuk kepustakaan adalah cara berpikir untuk mencari pola berkaitan dengan pengujian secara sistematis terhadap sesuatu untuk menentukan bagian, hubungan antarbagian, dan hubungannya dengan keseluruhan, menyusun dalam satuan yang dikategorisasikan, kemudian melakukan pengodean (coding) berdasarkan kategori-kategori yang telah ditetapkan, dan pemeriksaan keabsahan data. Sedangkan menurut Creswell (dalam Hamzah: 2020), analisis data adalah proses berkelanjutan yang membutuhkan refleksi terusmenerus terhadap data, mengajukan pertanyaan-pertanyaan analitis, dan menulis catatan singkat sepanjang penelitian. 
Analisis data dilakukan saat pengumpulan data berlangsung dan setelah selesai pengumpulan data. Apabila data yang diperoleh belum sesuai dengan tujuan penelitian, maka pengambilan data dilanjutkan sampai data yang diperoleh kredibel. Menurut Miles dan Huberman (dalam Hamzah: 2020) terdapat tiga macam kegiatan dalam analisis data kualitatif, yaitu :

\section{Reduksi Data}

Data yang diperoleh di lapangan dicatat secara teliti dan rinci. Reduksi data dilakukan untuk menghindari penumpukan data dengan merangkum, memilih hal pokok, memfokuskan pada hal penting, mencari tema dan pola, membuang yang tidak perlu hingga memberikan gambaran yang lebih jelas dan mempermudah untuk melakukan pengumpulan data selanjutnya.

\section{Penyajian Data}

Pada dasarnya, tidak terdapat ketentuan khusus mengenai format penyajian data dalam penelitian kualitatif, peneliti dapat menggunakan model apapun selama sajian data dapat dipahami maksud dan tujuannya serta memudahkan pengorganisasian dan penyusunanya. Misalnya, data disajikan dalam bentuk teks naratif atau matrix. Menurut Miles \& Huberman (dalam Hamzah: 2020), terdapat enam hal yang dilakukan dalam penyajian data :

Contact summary sheet, membuat kertas kerja yang berisi serangkaian fokus penelitian atau pertanyaan penelitian dengan mengulas kembali hasil catatan lapangan dan men- jawab singkat untuk mengembangkan kesimpulan.

Codes and coding, pengodean seluruh catatan yang telah disusun berdasarkan pertanyaan penelitian. Selanjutnya, kode-kode diorganisasikan sedemikian rupa agar dapat dikelompokkan berdasarkan segmen yang berhubungan dengan pertanyaan yang telah dirumuskan.

Pattern coding, pengkodean inferensial atau penjelasan merupakan cara mengelompokkan kesimpulan ke dalam bentuk yang lebih kecil berupa tema atau konstruk. Setelah itu, data dimasukkan ke dalam satuan analisis yang esensial.

Memoir, mengumpulkan data yang terhì̀mpun dari penelitian dari satu kesatuan yang saling terkait dan merepresentasikan suatu konsep yang utuh. 
Site analysis meeting, melakukan pertemuan dengan informan untuk menyimpulkan kondisi lapangan yang diarakan oleh serangkaian pertanyaan yang diajukan, kemudian dijawab dan dicatat selama pertemuan berlangsung.

Interim site summary, berisi sintesis atas pengetahuan yang berhasil didapatkan di lapangan dengan memeriksa hal-hal yang mungkin luput dari penelitian, kilas balik temuan, dan menentukan langkah penelitian selanjutnya.

\section{Verifikasi Data}

Istilah verifikasi sering digunakan secara bergantian dengan istilah validasi dalam penelitian. Dalam studi kualitatif, verifikasi mengandung maksud validasi, sedangkan dalam studi kuantitatif menggunakan istilah validasi meskipun sebenarnya mengandung makna verifikasi. Validasi adalah tingkat pencapaian kebenaran dari kesimpulan atau konklusi seperti halnya studi kuantitatif, validasi dalam penelitian kualitatif, diperhatikan dalam dua hal, yaitu validasi internal dan validasi eksternal.

Dalam penelitian kepustakaan ini pengambilan data dilakukan dengan wawancara, observasi, dan studi dokumentasi. Dalam konteks penelitian kepustakaan kegiatan wawancara dan observasi diubah menjadi analisi isi. Metode analisis isi digunakan untuk mengumpulkan muatan sebuah teks berupa kata-kata, makna gambar, simbol, gagasan, tema, dan segala bentuk pesan yang dikomunikasikan. Menurut Neuman (dalam Hamzah: 2020), langkah kerja metode analisis isi yaitu: a.Menentukan sampling, b.Menentukan variabel, c.Menyusun kategori pengodean, dan e.Menarik kesimpulan.

\section{HASIL DAN PEMBAHASAN}

\section{Tahap Perencanaan}

\section{Identifikasi Masalah}

Fenomena pendidikan di Indonesia di mana institusi pendidikan belum mampu berperan secara optimal dalam perkembangan SDM. Sekolah-sekolah cenderung mengutamakan kuantitas dan prestise bukan kualitas dan prestasi yang dimiliki oleh peserta didik, sehingga pengembangan potensi peserta didik kurang mendapatkan perhatian. Sehingga pendidikan belum mampu memerankan tugas dan fungsinya secara optimal. Hal ini terlihat bahwa masih banyak peserta didik yang belum mampu mengaktualisasikan potensi yang dimiliki. Potensipotensi yang ada pada diri mereka tidak dapat berkembang secara optimal, mereka yang 
mempunyai minat tidak dapat mengembangkan minat mereka secara baik, yang berkecerdasan tinggi kurang mendapat rangsangan dan fasilitas pendidikan sehingga minat dan kecerdasan yang dimiliki terbuang sia-sia dan tidak dapat tersalurkan dengan baik.

\section{Menetapkan Tujuan dan Kegunaan Penelitian}

Tujuan Penelitian ini adalah untuk membuktikan peran guru BK SMA dalam meningkatkan minat melanjutkan studi ke perguruan tinggi serta mengembangkan bahan ajar Peran Guru BK SMA dan Minat Melanjutkan Studi Ke Perguruan Tinggi. Hasil penelitian diharapkan dapat digunakan untuk memahami masalah, guru BK memberikan arahan dan informasi kepada peserta didik sesuai dengan minatnya, memecahkan masalah, dalam hal ini guru BK bertugas membantu peserta didik berkaitan dengan minat melanjutkan studi ke perguruan tinggi sesuai keinginannya serta dapat mengantisipasi masalah, penelitian ini berguna agar tidak terjadi masalah di dunia pendidikan, khususnya tentang minat melanjutkan studi ke perguruan tinggi yang peserta didik sebelumnya tidak memahami tentang hal tersebut.

\section{Metode Analisis}

Menurut Borgdgan \& Biklen (dalam Hamzah: 2020) berpendapat bahwa analisa data kualitatif termasuk kepustakaan adalah cara berpikir untuk mencari pola berkaitan dengan pengujian secara sistematis terhadap sesuatu untuk menentukan bagian, hubungan antarbagian, dan hubungannya dengan keseluruhan, menyusun dalam satuan yang dikategorisasikan, kemudian melakukan pengodean (coding) berdasarkan kategori-kategori yang telah ditetapkan, dan pemeriksaan keabsahan data. Sedangkan menurut Creswell (dalam Hamzah: 2020), analisis data adalah proses berkelanjutan yang membutuhkan refleksi terusmenerus terhadap data, mengajukan pertanyaan-pertanyaan analitis, dan menulis catatan singkat sepanjang penelitian.

\section{Sumber Data}

Sumber data dari penelitian ini yaitu dengan menggunakan 10 buku untuk dijadikan kajian teori. Buku-buku tersebut dipilih sesuai dengan tema permasalahan yang diambil oleh penulis. Sumber data dalam penelitian ini juga menggunakan 10 jurnal dan artikel dalam pengumpulan 
data ini. Selain itu juga ada yang diunduh dan dikaji melalui internet atau bersumber dari link /website.

\section{Tahap Pelaksanaan}

\section{Menentukan Metode Kepustakaan}

Metode yang digunakan dalam penelitian ini adalah metode analisis isi. Metode analisis isi atau teks digunakan untuk mengumpulkan muatan sebuah teks berupa kata-kata, makna gambar, simbol, gagasan utama, tema, dan segala bentuk pesan yang dapat dikomunikasikan. Metode analisis isi berusaha melihat konsistensi makna dalam sebuah teks yang dijabarkan dalam pola-pola terstruktur dan membawa peneliti kepada pemahaman sistem nilai dibalik teks.

Tujuan metode analisis isi untuk menguraikan dan menyimpulkan isi dari proses komunikasi lisan atau tulisan. Hal ini dilakukan dengan cara mengidentifikasi karakteristik tertentu pada pesan-pesan yang jelas secara objektif, sistematis, dan kuantitatif. Menurut Neuman (dalam Hamzah: 2020) langkah-langkah kerja metode analisi isi, yaitu menentukan sampling, menentukan variabel, menentukan variabel, menyusun kategori pengodean, dan menarik kesimpulan.

\section{Pengumpulan Data}

Pengumpulan data adalah upaya yang dilakukan untuk menghimpun informasi yang relevan dengan topik atau masalah yang akan atau sedang diteliti. Informasi dapat diperoleh dari buku-buku ilmiah, laporan penelitian, karangan-karangan ilmiah, tesis, disertasi, peraturan-peraturan, buku tahunan, ensiklopedia, dan sumber-sumber tertulis yang lain. Dalam penelitan ini penulis menggunakan sumber data yang akan dijelaskan sebagai berikut :

Pada jurnal Abdullah tahun 2016 dengan judul "Minat Siswa / Siswa Madrasah Aliyah (MA) Kota Kediri Melanjutkan Studi Ke Perguruan Tinggi", sekolah yang dijadikan sampel adalah MAN 2 Kota Kediri, SMA N 3 Kota Kediri, SMA N 2 Kota Kediri, SMA Pawyatan Dhaha, SMK Pawyatan Dhaha, SMA N 1 Kota Kediri, MAN 3 Kota Kediri. Hasil menunjukkan bahwa total skor responden sebesar 15.542, besar minat siswa SMA/MA Kota kediri melanjutkan ke perguruan tinggi $=15.542: 19.404=0,81$ atau $81 \%$ dari yang diharapkan. Hasil yang diharapkan 100\%, 
sehingga dapat disimpulkan bahwa minat siswa SMA/MA Kota Kediri untuk melanjutkan ke perguruan tinggi dapat dikatakan besar.

Pada jurnal Yulianti \& Samuel S.P tahun 2015 dengan judul "Minat Siswa Kelas XII SMA Negeri 1 Bolano Lambunu Untuk Melanjutkan Studi Ke Jenjang Perguruan Tinggi”, masalah yang dihadapi adalah siswa kelas XII SMA Negeri 1 Bolano Lambunu. Metode dalam jurnal penelitian ini menggunakan penelitian deskriptif kualitatif. Hasil penelitian diperoleh gambaran bahwa minat siswa-siswi kelas XII SMA Negeri I Bolano Lambunu khususnya kelas XII minat untuk melanjutkan studi ke jenjang perguruan tinggi sudah cukup bagus. Hal ini dapat terlihat dari beberapa pernyataan siswa yang dapat membangkitkan minat siswa, dengan jumlah yang dikomulatifkan jawaban sangat setuju dan setuju sejumlah 97,38\% hal ini menunjukan bahwa siswa menyadari dengan masuk perguruan tinggi sangat penting untuk meraih cita-cita siswa tersebut.

Pada jurnal Astuti, dkk tahun 2019 dengan judul "Peran Guru BK SMA Patra Dharma Balikpapan Dalam Meningkatkan Minat Melanjutkan Studi Ke Perguruan Tinggi", hasil penelitian dalam jurnal ini menunjukkan bahwa Peran Guru BK SMA Patra Dharma Balikpapan Dalam Meningkatkan Minat Lanjut Ke Perguruan Tinggi pada siswa yang peneliti temukan sangat baik. Disini guru BK berperan penting dan selalu mendukung juga memotivasi siswasiswinya untuk lanjut ke perguruan tinggi.

Pada jurnal Nisa tahun 2018 dengan judul "Peran Guru Bimbingan dan Konseling Dalam Meningkatkan Minat Melanjutkan Studi ke Perguruan Tinggi”, siswa yang dijadikan sampel penelitian ada 40 siswa yang terdiri dari 20 siswa pada kelas XII jurusan TKJ dan 20 siswa pada kelas XII jurusan AP di SMK Nurul Hikmah Bekasi. Metode yang digunakan adalah metode kualitatif. Berdasarkan hasil interpretasi data yang telah diinterpretasikan, terlihat interpretasi kategori Sangat Baik 0\%, kategori Baik 50\%, kategori Cukup 46,7\%, kategori Kurang Baik 3,3\%, dan kategori Sangat Kurang Baik 0\%. Dari data tersebut, maka dapat diinterpretasikan peran guru BK dalam meningkatkan minat siswa melanjutkkan studi ke perguruan tinggi dalam kategori baik, dan menunjukkan bahwa guru BK memberikan pemahaman tujuan melanjutkan studi ke perguruan tinggi, serta guru BK juga berperan memotivasi dan meningkatkan minat siswa dalam melanjutkan studi ke perguruan tinggi.

Pada jurnal Fadillah, dkk tahun 2019 dengan judul “Kajian Minat Studi Lanjut Siswa SMA/SMK Kota Bogor ke Perguruan Tinggi” populasi penelitian ini adalah seluruh siswa-siswi 
SMA/SMK Kelas XII di wilayah Kota dan Kabupaten Bogor, baik sekolah berstatus negeri maupun berstatus swasta. Sampel penelitian ini sebanyak 1024 orang siswa yang dijadikan responden. Hasil olah data menunjukkan bahwa tinggi/besarnya minat studi lanjut siswa SMA/SMK setelah lulus pada siswa siswi SMA/SMK di Kota Bogor menunjukan 51,5\% memiliki minat untuk melanjutkan studi sangat tinggi, 32,5\% memiliki minat tinggi/besar, 12,4\% biasa saja dan 3,6\% sisanya tidak memberikan jawaban. Dengan demikian maka hasil olah data tersebut menunjukkan bahwa kriteria interpretasi skor atas tinggi / besar minat studi lanjut siswa SMA / SMK di Kota Bogor berada di kisaran tinggi / besar yaitu sebesar 84\% yang berarti sangat kuat.

Pada Jurnal Khadijah tahun 2017 dengan judul “Analisis Minat Peserta Didik untuk Melanjutkan Pendidikan Tinggi” yang dilaksanakan di SMA Negeri 2 Tambang Kabupaten Kampar. Untuk menentukan jumlah sampel dalam penelitian ini dengan menggunakan Stratified Proportional Random Sampling, sehingga diperoleh sampel sebanyak 185 orang. Berdasarkan penelitian yang dilakukan di SMA Negeri 2 Tambang Kabupaten Kampar memperlihatkan bahwa sebagian besar responden 83,78\% memiliki minat yang sangat tinggi untuk melanjutkan pendidikan tinggi dan tidak ada satupun responden yang memiliki minat sangat rendah da $\mathrm{n}$ rendah.

Pada Jurnal Atalia tahun 2018 dengan judul “Minat Tamatan SMA Melanjutkan Pendidikan Ke Perguruan Tinggi: Lingkungan Teman Sebaya Dan Status Ekonomi" menunjukkan bahwa minat melanjutkan studi ke perguruan tinggi pada tamatan SMA dalam kategori rendah, karena faktor teman sebaya dan juga status ekonomi keluarga.

Pada penelitian Nandasari tahun 2019 dengan judul “Analisis Minat Melanjutkan Studi Ke Perguruan Tinggi Pada Siswa Kelas XII Dari Keluarga Nelayan" di SMA N 1 Pemangkat. Peneliti melakukan pengamatan dan meminta data dari sekolah mengenai jumlah siswa kelas XII yang berasal dari keluarga nelayan. Jumlah seluruh siswa kelas XII dari keluarga nelayan adalah 66 orang. Berdasarkan hasil penelitian dan pembahasan tentang minat melanjutkan studi ke perguruan tinggi pada siswa kelas XII dari keluarga nelayan di SMA N 1 Pemangkat dapat ditarik kesimpulan bahwa siswa kelas XII dari keluarga nelayan semuanya ingin melanjutkan ke perguruan tinggi.

Pada jurnal Setiaji dan Desy Rachmawati tahun 2017 dengan judul "Minat Melanjutkan Studi Ke Perguruan Tinggi SMK N Kota Semarang”, populasi dalam penelitian ini adalah seluruh 
siswa kelas XI SMK Negeri se-Kota Semarang tahun ajaran 2017/2018 yang diambil berdasarkan karakteristik bidang keahlian yang berjumlah 5.067 siswa. Berdasarkan kategori dekriptif menunjukkan bahwa tingkat variabel minat melanjutkan studi ke perguruan tinggi termasuk dalam kategori tinggi. Hal ini menunjukkan bahwa siswa SMK Negeri se-Kota Semarang memiliki perasaan tertarik, senang dan berkeinginan untuk melanjutkan studi ke perguruan tinggi.

Pada jurnal Setiawan tahun 2018 dengan judul "Minat Siswa SMK Melanjutkan Studi Ke Perguruan Tinggi Pada Siswa Kelas XII Jurusan Akuntansi SMK Dharma Putra Banjarmasin", hasil menunjukkan bahwa rata-rata siswa SMK Dharma Putra Banjarmasin ingin melanjutkan pendidikannya ke perguruan tinggi karena alasan yang datang dari diri mereka sendiri, terutama sekali tentang karir.

Dalam buku Slameto (2015) dengan judul "Belajar dan Faktor-Faktor Yang Mempengaruhinya", dijelaskan tentang minat, adapun tentang motivasi dan juga faktor-faktor yang dapat memengaruhinya. Mengembangkan minat terhadap sesuatu pada dasarnya adalah membantu peserta didik melihat bagaimana hubungan antara pendidikan yang diharapkan oleh peserta didik. Proses ini berarti menunjukkan pada peserta didik bagaimana pengetahuan atau informasi tertentu memengaruhi dirinya. Cara yang efektif untuk mengembangkan minat pada suatu subyek yang baru adalah dengan menggunakan minat-minat siswa yang telah ada. Dengan begitu siswa lebih mudah dalam menentukan minat yang sesuai dengan kemauan atau ketertarikannya pada suatu objek tertentu. Motivasi juga dibutuhkan dalam hal ini demi tercapainya hasil yang optimal. Orangtua dan guru dapat memberikan arahan mengenai minat yang dimiliki oleh individu atau seseorang.

Dalam buku Noor (2019) dijelaskan bahwa guru adalah seseorang yang berprofesi sebagai pengajar dan pendidik. Bisa dikatakan guru merupakan pemegang kondisi yang sangat menentukan kualitas SDM di suatu negara. Guru yang berkualitas dan profesional akan menghasilkan murid yang berkualitas pula. Tanpa adanya peningkatan kualitas guru, maka upaya untuk meningkatkan kualitas pendidikan hasilnya akan sia-sia. Peran guru sangat berpengaruh dalam pendidikan, semua akan terlaksana dengan baik dan optimal dengan berkolaborasi dengan berbagai pihak sekolah maupun orang tua murid demi terlaksananya program BK. 
Dalam buku Susanto (2018) dijelaskan bahwa bimbingan merupakan bagian dari program pendidikan secara keseluruhan yang membantu peserta didik dalam mengembangkan kesempatan yang dimiliki oleh setiap individu. Layanan BK merupakan bantuan yang diberikan kepada seseorang atau individu yang bersangkutan, sehingga individu tersebut dapat mencapai taraf perkembangan dan kebahagiaan yang optimal dalam menjalani proses pemahaman, penerimaan, dan penyesuaian diri dan di lingkungan dimana ia berada.

Dalam buku Sudrajat (2016) dijelaskan bahwa proses pemberian bantuan guru BK kepada peserta didik untuk memahami pertumbuhan, perkembangan, eksplorasi, aspirasi dan pengambilan keputusan karir sepanjang rentang hidupnya secara rasional dan realistis berdasar informasi potensi diri dan melihat kesempatan yang tersedia di lingkungan hidupnya untuk mencapai kesuksesan dalam kehidupannya.

\section{PEMBAHASAN}

Dalam pendidikan di SMA, guru BK atau konselor berperan membantu tercapainya perkembangan pribadi, sosial, belajar, dan karir peserta didik atau konseli. Peran guru BK sangat dibutuhkan dalam dunia pendidikan, khususnya di bidang karir, karena setelah lulus dari bangku SMA tentunya peserta didik juga perlu memahami tentang melanjutkan studi ke perguruan tinggi. Dan untuk itu diperlukannya bimbingan juga pengarahan terkait dengan minat melanjutkan studi ke perguruan tinggi. Selain itu, guru BK juga memberikan informasi kepada peserta didik atau konseli dalam dalam mengembangkan potensi-potensi yang dimilikinya tersebut. Potensi tersebut dapat berupa bakat maupun minat.

Menurut Slameto (2015) minat adalah suatu rasa lebih suka dan rasa ketertarikan pada suatu hal atau aktivitas, tanpa ada yang menyuruh. Minat pada dasarnya adalah penerimaan akan suatu hubungan antara diri sendiri dengan sesuatu di luar diri. Semakin kuat atau dekat hubungan tersebut, semakin besar minat. Minat sering dihubungkan dengan keinginan atau ketertarikan terhadap sesuatu yang datang dari dalam diri seseorang tanpa ada paksaan dari luar. Sedangkan menurut Hilgard (dalam Slameto: 2015) mengatakan bahwa minat adalah kecenderungan yang tetap untuk memperhatikan dan mengenang beberapa kegiatan. Kegiatan yang diminati seseorang, diperhatikan terus-menerus yang disertai dengan rasa senang. Jadi berbeda dengan perhatian, karena perhatian sifatnya sementara (tidak dalam waktu yang 
lama) dan belum tentu diikuti dengan perasaan senang, sedangkan minat selalu diikuti dengan perasaan senang dan dari situ diperoleh kepuasan.

Minat juga memiliki beberapa fungsi. Hidayat (dalam Pratiwi 2015) minat berhubungan erat dengan sikap kebutuhan seseorang dan mempunyai fungsi sebagai berikut : 1) Sumber motivasi yang kuat untuk belajar, 2) Minat memengaruhi bentuk intensitas apresiasi anak, dan 3) Menambah kegairahan pada setiap kegiatan yang ditekuni seseorang. Minat berfungsi sebagai pendorong keinginan seseorang, penguat hasrat dan sebagai penggerak dalam berbuat yang berasal dari dalam diri seseorang untuk melakukan sesuatu dengan tujuan dan arah tingkah laku sehari-hari. Hal ini diterangkan oleh Sardiman (dalam Damayanti: 2014) yang menyatakan fungsi minat, yaitu : 1) Mendorong manusia untuk berbuat, 2) Menentukan arah perbuatan, dan 3) Menyeleksi perbuatan.

Dalam Peraturan Menteri Pendidikan Nasional Republik Indonesia Nomor 27 Tahun 2008 tentang Standar Kualifikasi Akademi dan Kompetensi Konselor, yang menyatakan bahwa kualifikasi akademik konselor dalam satuan pendidikan pada jalur pendidikan formal dan nonformal adalah: (i) sarjana pendidikan (S-1) dalam bidang bimbingan dan konseling, (ii) berpendidikan profesi konselor. Kompetensi konselor meliputi kompetensi pedagogik, kompetensi kepribadian, kompetensi sosial, dan kompetensi profesional.

Dalam penelitian ini guru BK berperan demi tercapainya perkembangan karir peserta didik/konseli terkait dengan minat melanjutkan studi ke perguruan tinggi. Meskipun guru BK atau konselor memegang peranan kunci yang penting dalam sistem BK di sekolah, dukungan dari kepala sekolah juga sangat dibutuhkan. Sebagai penanggung jawab pendidikan di sekolah, kepala sekolah bertanggung jawab atas terselenggaranya layanan BK. Selain itu, guru BK atau konselor sekolah harus berkolaborasi dengan berbagai pihak, seperti guru bidang studi, wali kelas, komite sekolah, orang tua peserta didik, dan pihak-pihak lain yang relevan, tanpa adanya kerjasama dengan pihak sekolah program BK tidak akan berjalan secara optimal. Karena keberadaan guru BK sangat penting dalam mendukung dan meningkatkan mutu pendidikan di sekolah.

Peran guru BK SMA dalam meningkatkan minat melanjutkan studi ke perguruan tinggi sangat dibutuhkan dalam rangka tercapainya hasil perkembangan pada peserta didik secara optimal dan seseuai dengan kemampuan yang dimiliki oleh peserta didik. Karena minat pada individu maupun seseorang didalamnya juga ada banyak faktor-faktor yang dapat 
mempengaruhi minat tersebut. Sehingga disini peran guru BK lah yang sesuai dengan kebutuhan peserta didik mengenai minat dan potensinya. Selain itu motivasi dari orang tua siswa dan guru juga berpengaruh terhadap peserta didik.

Faktor yang memengaruhi minat siswa dalam melanjutkan studi ke perguruan tinggi menurut Hurlock (dalam Nandasari: 2019) yaitu "sikap teman sebaya, sikap orang tua, nilainilai yang menunjukkan keberhasilan dan dukungan sosial”. Sedangkan menurut Ridwan (dalam Saputra: 2017) faktor-faktor yang memengaruhi minat melanjutkan studi ke perguruan tinggi terbagi menjadi dua golongan yaitu : faktor internal dan faktor eksternal. Menurut Slameto (2015) mengungkapkan bahwa faktor internal merupakan faktor yang berasal dari dalam diri siswa. Sedangkan faktor eksternal adalah faktor yang berasal dari luar diri siswa (Slameto: 2015).

Dari penjelasan faktor-faktor di atas maka dapat disimpulkan mengapa guru BK berperan dalam meningkatkan minat melanjutkan studi ke perguruan tinggi kaitannya dengan berjalannya proses layanan BK di sekolah. Hal ini dapat berpengaruh terhadap motivasi siswa di sekolah. Oleh karena itu, guru BK dapat membantu peserta didik untuk mengetahui apa saja informasi mengenai minat melanjutkan studi ke perguran tinggi, dan juga dapat mempelajari faktor yang dapat memengaruhi. Dengan cara memberikan informasi tentang minat melanjutkan studi ke perguruan tinggi, yang dilakukan oleh guru BK.

Adapun faktor internal yang paling mempengaruhi peserta didik dalam meningkatkan minat melanjutkan ke perguruan tinggi, karena minat adalah suatu rasa ketertarikan dari diri seseorang tanpa ada paksaan dari siapapun. Jadi seseorang harus mengetahui apa saja faktorfaktor yang dapat menghambat minat seseorang. Dengan mengetahui faktor-faktor tersebut diharapkan seseorang lebih memahami minat yang sesuai apa yang diminatinya. Dan untuk mengoptimalkan semua itu perlu adanya dorongan atau motivasi yang ditunjukkan guru BK kepada peserta didik.

Untuk itu peran guru BK dalam memberikan bimbingan kepada peserta didik atau konseli besar pengaruhnya terhadap seseorang atau individu. Pemahaman akan minat melanjutkan studi ke perguruan tinggi akan tercapai jika pesan atau informasi dapat sampai ke konseli atau peserta didik. Berkaitan dengan hal itu, penting bagi peserta didik atau konseli mengetahui apa saja informasi yang sebelumnya belum mereka pahami, dan setelah adanya pemberian informasi yang diberikan oleh guru BK, peserta didik dapat memantapkan lagi minatnya. 
Bahwasannya minat itu ada pada perasaan diri sendiri, karena ketertarikan pada sesuatu objek tertentu.

Guru BK dalam meningkatkan minat melanjutkan studi ke perguruan tinggi berperan untuk menarik minat siswa untuk lanjut studi dengan cara mengadakan sosialisasi tentang perguruan tinggi di Indonesia baik yang swasta maupun negeri, guru BK berperan memotivasi siswa lanjut studi ke perguruan tinggi dengan memberikan pengembangan potensi yang dimiliki peserta didik untuk mengikuti pendidikan yang lebih tinggi melalui layanan BK informasi terutama dalam bimbingan karir peserta didik, agar peserta didik tidak salah memilih jurusan yang sesuai minat peserta didik karena hal tersebut akan sangat berpengaruh dalam menentukan karirnya setelah lulus. Karena SMA merupakan sekolah menengah atas yang lebih menekankan pada penguasaan ilmu pengetahuan yang bersifat teoretis sebagai bekal untuk melanjutkan studi ke perguruan tinggi. Dengan cara memberikan pengarahan dan layanan informasi kepada peserta didik atau konseli.

Peran guru BK SMA sangat berpengaruh dalam membantu peserta didik atau konseli dalam menentukan minat sesuai dengan kesenangan atau kemauan dirinya dalam melanjutkan studi ke perguruan tinggi. Adapun tugas-tugas yang dimiliki oleh seorang guru BK atau konselor yang ditemukan oleh Salahudin (dalam Hayati: 2016) antara lain Mengadakan observasi terhadap situasi atau keadaan sekolah, baik mengenai peralatan, tenaga, penyelenggara, maupun aktivitas lainnya, Kegiatan penyusunan program dalam bidang bimbingan pribadi sosial, bimbingan belajar, bimbingan karir, serta semua jenis layanan termasuk kegiatan pendukung yang dihargai sebanyak 12 jam, Kegiatan melaksanakan pelayanan bimbingan pribadi, bimbingan sosial, bimbingan belajar, bimbingan karir, serta semua jenis layanan termasuk kegiatan pendukung yang dihargai sebanyak 18 jam, Kegiatan evaluasi pelaksanaan layanan dalam bimbingan pribadi, bimbingan sosial, bimbingan belajar, bimbingan karir serta semua jenis layanan termasuk kegiatan pendukung yang dihargai sebanyak 6 jam, Menyelenggarakan bimbingan terhadap siswa, baik yang bersifat preventif, perservatif maupun yang bersifat korektif atau kuratif, dan Sebagaimana guru mata pelajaran, guru pembimbing atau konselor yang membimbing 150 orang siswa dihargai sebanyak 18 jam, sebaliknya dihargai sebagai bonus.

Untuk mengembangkan minat pada peserta didik terutama di bidang karir untuk melanjutkan studi ke perguruan tinggi, guru BK melaksanakan bimbingan karir dengan 
menggunakan layanan informasi pada saat jam pembelajaran BK berlangsung. Dalam bimbingan ini guru BK mengarahkan untuk pemantapan dan pemahaman diri peserta didik terkait seberapa jauh pemahaman tentang dunia kerja, peserta didik dapat mengetahui jenisjenis pekerjaan yang sesuai dengan minat dan bakatnya, mampu mengembangkan hubungan positif dalam dunia kerja dan bagaimana jenis-jenis pendidika/latihan yang berguna untuk suatu pekerjaan atau pendidikan tertentu yang diminati oleh peserta didik.

Berdasarkan dari hasil penelitian dan pembahasan dari beberapa sumber-sumber di atas dapat diketahui mengenai keberhasilan jurnal penelitian bahwa peran guru BK SMA dapat meningkatkan minat melanjutkan studi ke perguruan tinggi. Keberhasilan peran guru BK dalam memberikan pengarahan maupun layanan informasi kepada peserta didik mampu membuat peserta didik paham akan pentingnya pendidikan dan ingin melanjutkan studi ke perguruan tinggi. Dalam hal ini dapat dikatakan peserta didik paham akan minatnya dan mampu untuk mengambil keputusan dengan bijaksana untuk dirinya sendiri yang sesuai dengan minat. Keberhasilan meningkatkan minat siswa melanjutan studi ke perguruan tinggi juga tak lepas dari kerjasama antar pihak sekolah dan juga orang-orang yang berpengaruh terhadap diri peserta didik atau konseli, seperti orang tua peserta didik dan orang-orang yang berada di lingkungan dimana peserta didik tinggal.

\section{SIMPULAN}

Berdasarkan hasil penelitian dapat disimpulkan bahwa guru BK memberikan pemahaman tentang melanjutkan studi ke perguruan tinggi, guru BK memberikan layanan BK untuk membantu siswa yang belum paham mengenai minat melanjutkan studi ke perguruan tinggi, serta guru BK juga berperan memotivasi dan meningkatkan minat siswa dalam melanjutkan studi ke perguruan tinggi. Program layanan BK telah diberikan kepada peserta didik terkait motivasi dan minat melanjutkan studi ke perguruan tinggi. Tujuan penelitian ini untuk mengetahui peran guru BK SMA dapat meningkatkan minat melanjutkan studi ke perguruan tinggi.

\section{DAFTAR RUJUKAN}

Abdullah, M. 2016. Minat Siswa/Siswi Sekolah Menengah Atas (SMA)/Madrasah Aliyah (MA) Kota

Kediri Melanjutkan Studi Di Perguruan Tinggi. Jurnal Realita, Vol.14, No.2, 234-245. 
Armalita, Sinta. 2016. Faktor-Faktor Yang Mempengaruhi Minat Untuk Melanjutkan Studi Ke Perguruan Tinggi Siswa Kelas XII Jurusan Tata Boga Di SMK Negeri 4 Dan SMK Negeri 6 Yogyakarta. Yogyakarta: Universitas Negeri Yogyakarta. [Online]. Diunduh pada eprints.uny.ac.id.. Pada tanggal 15 Mei 2020.

Astuti, Casmudi, dan Sugianto. 2019. Peran Guru Bimbingan dan Konseling SMA Patra Dharma Balikpapan Dalam Meningkatkan Minat Melanjutkan Studi ke Perguruan Tinggi Tahun Ajaran 2018/2019. Jurnal Edueco Universitas Balikpapan, Vol.2, No.2 Desember 2019.

Atalia. 2018. Minat Tamatan Sma Melanjutkan Pendidikan Ke Perguruan Tinggi: Lingkungan Teman Sebaya Dan Status Ekonomi. Jurnal Ranah Research, Vol. 1 No. 1 (2018).

Damayanti, Aslina. 2014. Pengaruh Minat Mengikuti Layanan Bimbingan Kelompok Terhadap Kecerdasan Spiritual Siswa Di Sekolah Menegah Atas Negeri 1 Kunto Darussalam. Skripsi thesis. Riau: Universitas Islam Negeri Sultan Syarif Kasim Riau. [Online]. Diunduh pada repository.uin-suska.ac.id. Pada tanggal 2 April 2020.

Eriyono, M.E. 2013. Penerapan Kompetensi Profesional Guru Bimbingan Dan Konseling Pasca Sertifikasi (Studi Deskriptif Pada Guru Bimbingan Dan Konseling SMP Negeri Se-Kabupaten Rembang Tahun Ajaran 2012/2013). Semarang: Universitas Negeri Semarang. [Online]. Diunduh pada lib.unnes.ac.id. Pada tanggal 2 Juli 2020.

Fadillah, A.S., dan Iswandi S. 2019. Kajian Minat Studi Lanjut Siswa SMA/SMK Kota Bogor Ke Perguruan Tinggi. Jurnal Analisis Sistem Pendidikan Tinggi, Vol. 3 No. 1 2019, Hal. 53-62.

Hamzah, Amir. 2020. Metode Penelitian Kepustakaan (Library Research). Malang: Literasi Nusantara.

Handaka, I.B dan Cecep Maulana. 2017. Peran Guru Bimbingan Dan Konseling Dalam Implementasi Gerakan Literasi Nasional. Jurnal Prosiding Seminar Bimbingan dan Konseling, Vol. 1, No. 1, 2017, hlm. 227-237.

Hayati, Fitri. 2016. Peran Guru Bimbingan Dan Konseling Dalam Mengatasi Kecenderungan Perilaku Agresif Peserta Didik Di MA. Jurnal Manajer Pendidikan, Vol.10, No.6, hlm.603-07.

Indriyanti, N., Siswandari, dkk. 2013. Faktor-faktor Yang Mempengaruhi Minat Melanjutkan Pendidikan ke Perguruan Tinggi Pada Siswa kelas XII Akuntansi SMK Negeri 6 Surakarta tahun 2013. Jurnal Jupe UNS, Vol.1, No.2 1-10.

Ismail dan Bambang T. 2011. Pedoman Menulis Skripsi. Sukoharjo: Univet Bantara Press.

Kasih, Fitria. 2017. Profil Kompetensi Guru Bimbingan Dan Konseling Dalam Pelayanan Kelompok Di SMA Sumatra Barat. Jurnal Counseling Care, Vol.1, No.1, 13-26.

Khadijah, S., Henny, dkk. 2017. Analisis Minat Peserta Didik Untuk Melanjutkan Pendidikan Tinggi. Jurnal Pendidikan Ilmu Sosial, Vol. 26, No. 2, Desember 2017. 
Lestari, Mugi. 2013. Kompetensi Profesional Guru Bimbingan Dan Konseling Dalam Pelaksanaan Pelayanan Bimbingan Dan Konseling Di SMP Negeri Se-Kota Cilacap Tahun Pelajaran 2012/2013. Semarang: Universitas Negeri Semarang. [Online]. Diunduh pada https://lib.unnes.ac.id. Pada tanggal 20 Mei 2020.

Limbong, Mesta. 2017. Upaya Guru Melakukan Pelayanan Bimbingan Dan Konseling Pendidikan Dasar 9 Tahun. Jurnal Ilmiah Dalam Implementasi Kurikulum Bimbingan Dan Konseling Berbasis KKNI, 4- 6 Agustus 2017. [Online]. Diunduh pada journal2.um.ac.id. Pada tanggal 15 Juni 2020.

Nandasari, Wika. 2019. Analisis Minat Melanjutkan Studi Ke Perguruan Tinggi Pada Siswa Kelas XII Dari Keluarga Nelayan. Pontianak: Universitas Tanjungpura Pontianak. [Online]. Diunduh pada jurnal.untan.ac.id. Pada tanggal 11 Mei 2020.

Nisa, Afiatin. 2018. Peran Guru Bimbingan dan Konseling Dalam Meningkatkan Minat Melanjutkan Studi ke Perguruan Tinggi. Jurnal Bimbingan dan Konseling (E Journal) 05 (1), 2018, 01-08.

Noor, Moh. 2019. Guru Profesional dan Berkualitas. Semarang: ALPRIN.

Putri, N.V. 2019. Tingkat Kompetensi Guru Bimbingan Dan Konseling Merencanakan Program BK Di Sekolah (Studi Deskriptif Kompetensi Merencanakan Program BK Guru-guru MGBK SMA/MA Sleman). Yogyakarta: Universitas Sanata Dharma Yogyakarta. [Online]. Diunduh pada repository.usd.ac.id. Pada tanggal 5 Juli 2020.

Rifma. 2016. Optimalisasi Pembinaan Kompetensi Pedagogik Guru. Jakarta: Prenamediagroup.

Rukaya. 2019. Aku Bimbingan dan Konseling. Bogor: Guepedia.

Saputra, J. 2017. Upaya Guru Bimbingan Konseling Dalam Meningkatkan Minat Melanjutkan Ke Perguruan Tinggi Di SMA Negeri 1 Membalong Kelas XII Tahun Ajaran 2016/2017. Yogyakarta: Universitas PGRI Yogyakarta. [Online]. Diunduh pada repository.upy.ac.id. Pada tanggal 17 Mei 2020.

Setiaji, K., dan Desy, R. 2017. Minat Melanjutkan Studi Perguruan Tinggi Siswa SMK N Kota Semarang. Jurnal Pendidikan Ekonomi, Vol.10, No.1.

Setiawan, Reksa. 2018. Minat Siswa SMK Melanjutkan Studi Ke Perguruan Tinggi Pada Siswa Kelas XII Jurusan Akuntansi SMK Dharma Putra Banjarmasin. Jurnal Ilmiah Ekonomi Bisnis, Jilid 4, Nomor 2, Juli 2018, Hal. 176-190.

Slameto. 2015. Belajar Dan Faktor-Faktor Yang Mempengaruhinya. Jakarta: Rineka Cipta.

Sundah, A.J.A .2018. Psikologi Konseling. Malang: CV.Seribu Bintang.

Susanto, Ahmad. 2018. Bimbingan dan Konseling di Sekolah Konsep,Teori, dan Aplikasinya. Jakarta : Prenadamedia Group. 
Syahputra, Edy. 2020. Snowball Throwing Tingkatkan Minat dan Hasil Belajar. Sukabumi: Haura Publishing.

Tim. 2016. Panduan Operasional Penyelenggaraan Bimbingan Dan Konseling Sekolah Menengah Atas (SMA). Jakarta: Kemendikbud.

Undang-Undang Republik Indonesia Nomor 14 Tahun 2005 Tentang Guru dan Dosen.

Undang-Undang Republik Indonesia Nomor 20 tahun 2008 tentang Sistem Pendidikan Nasional.

Wahyuni, S.A., dan Nailul, F. 2015. Peran Guru Bimbingan Dan Konseling Dalam Mengembangkan Minat Dan Bakat Program Pilihan Studi Keterampilan Peserta Didik MAN 1 Magelang. Jurnal Hisbah, Vol. 12, No. 2 Desember 2015.

Yulianti, N.K.E., dan Samuel, S.P. 2015. Minat Siswa Kelas XII SMA Negeri 1 Bolano Lambuno Untuk Melanjutkan Studi ke Jenjang Perguruan Tinggi. Jurnal Geo Tadulako, Vol.3, No.6 Desember 2015.

Zed, Mestika. 2017. Metode Penelitian Kepustakaan. Jakarta: Yayasan Pustaka Obor Indonesia. 